\title{
Seat Belt Syndrome and the Submarine Effect: A Case Report*
}

\author{
Raquel Cobos Cuesta, Isidro Martínez Casas, Francisco Jiménez Armenteros, Angela Ximena Argote Camacho \\ and Jose María Capitan Vallvey
}

General Surgery Department, Jaen General Hospital, Spain

Corresponding author:

Raquel Cobos Cuesta, MD

Avda. Andalucía №9 10izqda

C.P 23005 Jaén

E-mail: raquelcoboscuesta@hotmail.com

\footnotetext{
* This work has been presented as communication at the $18^{\text {th }}$ European Congress of Trauma and Emergency Surgery in Bucarest May 7-9, 2017
}

\begin{abstract}
Rezumat
Sindromul centurii de siguranță și efectul de submarin: o prezentare de caz

Semnul centurii de siguranță este un indicator al leziunilor interne severe în $30 \%$ din cazuri. În cadrul "efectului de submarin", corpul glisează pe dedesubtul centurïi, care acționează ca un pivot. "Sindromul centurii de siguranță" descrie prezența semnului centurii de siguranță în asociere cu o leziune intra-abdominală sau a coloanei vertebrale. Prezentăm cazul unui şofer implicat într-un accident rutier la care leziunile severe de țesut moale şi leziunile viscerale au fost cauzate de o centură de siguranță în două puncte, reproducând un "sindromul al centurii de siguranță" complet.
\end{abstract}

Cuvinte cheie: sindromul centurii de siguranțã, efectul de submarin

\section{Abstract}

The seatbelt sign is indicative of severe internal lesions in as many as $30 \%$ of cases. In the "submarine effect" the body slides below the belt, acting like hinge. "Seatbelt syndrome" describes the presence of the seat belt sign plus an intra-abdominal or spinal injury. We present the case of a driver in a car accident in whom severe soft tissue and visceral lesions were caused by a two-point seat-belt reproducing a complete "seatbelt syndrome".

Key words: seatbelt syndrome, submarine effect 


\section{Introduction}

Seatbelt sign is the characteristic pattern of contusion across the chest wall and abdomen seen in a restrained passenger involved in road-traffic collisions. It is indicative of an internal injury in as many as $30 \%$ of cases seen in the emergency department (1).

"Seat-belt syndrome" is a result of the pressure that the belt causes along its course and describes the presence of the seat belt sign plus an intra-abdominal or spinal injury.

\section{Case Report}

A 30-year-old male suffered a traffic accident. He was restrained with a two-points safety seatbelt that provoked wall and abdominal cavity injuries. He presented in the Emergency Room with the "seatbelt sign" and acute abdomen. Patient was initially stable. Palpable lesions include rectal muscle transection, and intestinal perforations, break of right psoas, left common iliac artery and vein thrombosis were highlighted on Body CT (Fig. 1). The patient proceed to urgent revascularization and damage control surgery: sigmoidectomy, cecum Resection without anastomosis and packing were performed. Compartment syndrome developed in the early postoperative period and after transfer to our institution a second surgery was mandatory: hemostasis and decompressive laparostomy with vacuum closure. Lately, in a third procedure intestinal reconstruction was carried out. Severe abdominal wall injury and retraction precluded closure and a substitution mesh was needed. In a fourth surgery, after onset of hypogastric fasciitis, discharge incisions and fasciotomy were done. After several weeks with vacuum therapy (Fig. 2A), the abdomen was closed with substitution mesh under the skin and soft tissue. Several ambulatory cures were needed after discharge (Fig. 2B).

\section{Discussion}

This case reproduces a complete "seatbelt syndrome". The damage was caused by the twopoints safety seatbelt affecting the abdominal wall and viscera. In the "submarine effect" the body slides below the belt, acting like hinge. Bad use of two-points seatbelt, already for laxness, laying it over the iliac spines or for incorrect attitude on sitting down, can cause important abdominal injuries, even lethal in traffic accidents.

Mechanical forces from seatbelt cause different types of injuries in traffic accidents, which are the result of kinetic energy dissipation through the body as the seat-belt restricts the passenger, preventing ejection from the seat (2).

Abdominal ecchymosis or chafing usually reflects important abdominal wall and cavity injuries. Wall damage is caused by knife-effect shearing the muscles. Intestinal injury is
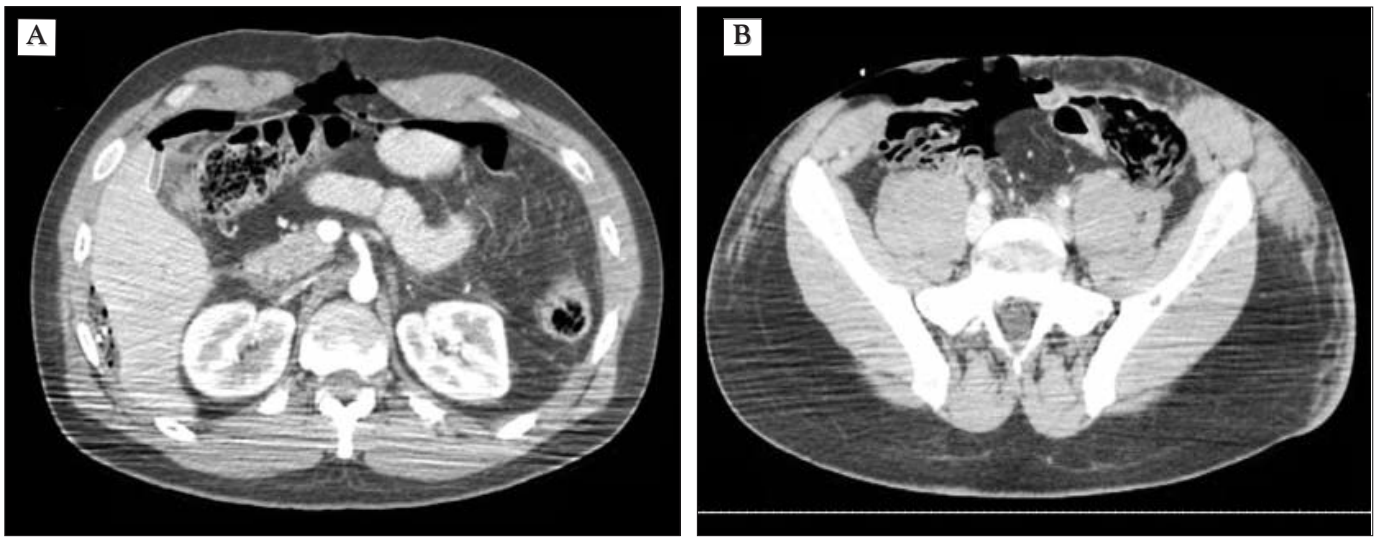

Figure 1. CT Showing rupture of the right rectal muscle, pneumoperitoneum (A) and left iliac vein thrombosis (B) 

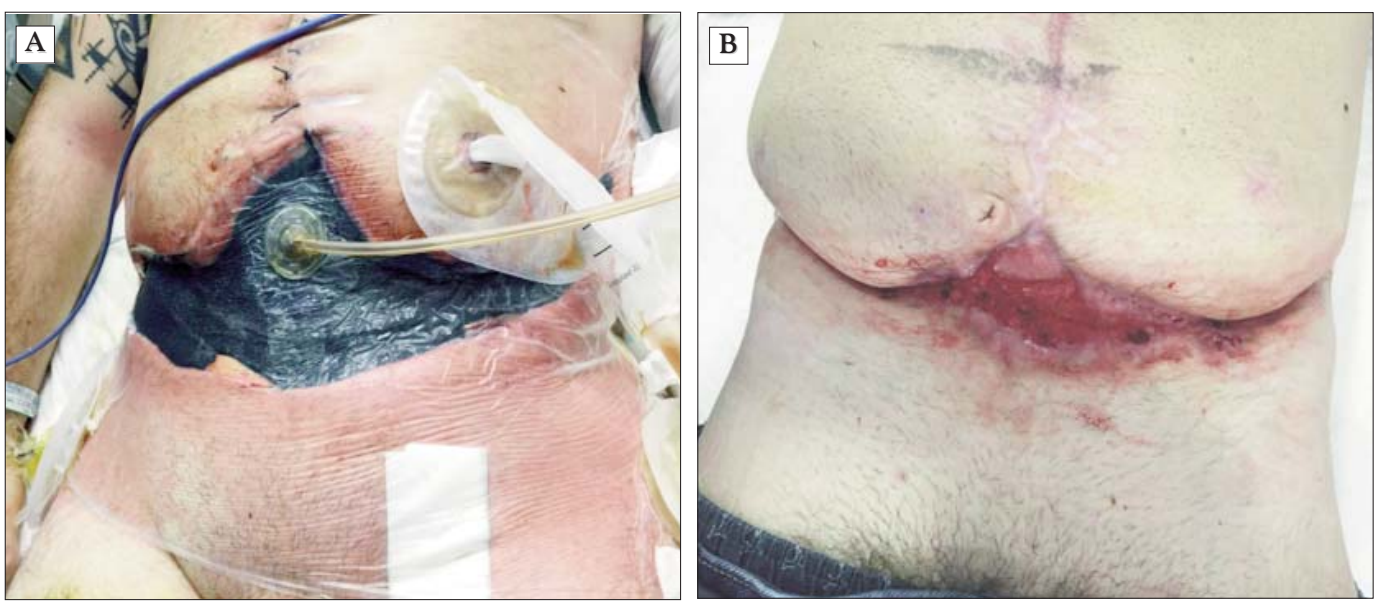

Figure 2. Vacuum therapy after the onset of fascitis $(A)$ and result at discharge with visible substitution mesh over the granulation tissue (B).

result of the sum of closed handle obstruction, increasing intraluminal pressure, and torsion forces that provoke the rupture of the intestinal wall (3).

Although seat belt injuries to the abdominal aorta and the carotid artery have been reported, there are only two previous reports in the literature of seat belt injury to the common iliac artery (4). This case originality lies in that there are no reports in literature of psoas transection without lumbar spine fractures after traffic accidents.

Intestinal injuries are more common in patients wearing a seat belt than those who travel unrestrained and a visible seatbelt contusion is associated with a threefold higher incidence of intestinal perforation (5). As such, clinicians should have a high degree of suspicion for other injuries in all patients presenting with visible seatbelt bruising.

\section{Conclusion}

Correct use of safety seatbelts is of capital importance to minimize injuries in traffic accidents, but its use can cause devastating soft tissue and visceral lesions the clinicians should be aware when assessing a trauma patient.

\section{References}

1. Masudi T, McMahon HC, Scott JL, Lockey AS. Seat belt-related injuries: A surgical perspective. J Emerg Trauma Shock. 2017; 10(2):70-3.

2. DGT. Tráfico y seguridad vial. Cinturón de seguridad. 2017. Num 239. Especial. Recovered from: http://revista.dgt.es/es/hemeroteca/

3. Agrawal A, Inamadar PI, Subrahmanyam BV. Seat belt sign and its significance. J Family Med Prim Care. 2013;2(3):288-90.

4. Gupta N, Auer A, Troop Br. Seat Belt-Related Injury to the Common Iliac Artery: Case Report and Review of the Literature. J TraumaInjury Infection \& Critical Care. 1998;45 (2):419-21.

5. O'Kelly F, O'Brien GC, Broe PJ. Severe abdominal injuries sustained in an adult wearing a pelvic seatbelt: a case report and review of the literature. Ir J Med Sci. 2008;177(4):385-7. 